\title{
長期暴露試験体の鉄筋質量減少率に基づく 断面修復工法の補修効果の評価 \\ EVALUATION OF EFFECT ON REPAIR OF SECTION REPAIR METHOD OF CONSTRUCTION BASED ON REINFORCING BARS MASS DECREASE RATE OF THE LONG-TERM EXPOSURE TEST BODY
}

\author{
西村眞 治*，桝田佳 寛**，鹿毛忠継***，松林裕二**** \\ Shinji NISHIMURA, Yoshihiro MASUDA, Tadatsugu KAGE \\ and Yuji MATSUBAYASHI
}

\begin{abstract}
This paper reports the results of outdoor exposure test on the repair performance on corrosion of reinforcing bar in salt containing concrete by various repairing materials. When there is much chlorination amount of material in the concrete, effect on repression of the reinforcing bars corrosion by the repair method of construction can't be expected very much. When the repair of the section repair part is done, that countermeasure is important from showing a tendency of progressing in the part of the boundary remarkably as for the reinforcing bars corrosion after the repair.

If chipping isn't taken to the back of the reinforcing bars, the effect of rust is prevented material, section repair material, When chlorination amount of material increases, corrosion spreads out in surface direction and depth direction as well.
\end{abstract}

Keywords: chloride ion, corrosion of reinforcing bar, chipping, primer, section recovery material, mass decrease rate 塩化物イオン，鉄筋腐食，はつり，鉄筋防錆材，断面修復材，質量減少率

\section{1. はじめに}

中性化や塩害によって鉄筋が腐食し、コンクリートにひび割れ、 浮き、剥落等の損傷が生じた場合の補修工法として、コンクリート の劣化部分をはつり取り、鉄筋の錆落としをして防錆処理を施し、 はつり取ったコンクリート部分を埋め戻す、いわゆる断面修復工法 が一般的に行われている。この工法の補修効果について、筆者らは、 断面修復工法を施した状況を模擬した試験体の長期にわたる暴露試

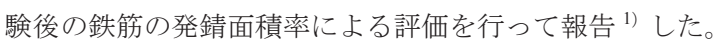

しかし、鉄筋腐食度の評価は、表面的な発錆面積率だけでなく、 深さ方向への進行状況についても評価し得る質量減少率によること がより重要であると考えられる。また、断面修復工法の補修効果の 評価では、後でコンクリートをはつり取って補修した部分（補修 部）以外のところで腐食が進行することがあるので、外観上は健全 でコンクリートをはつり取らず補修しなかった部分（以下、無補修 部）および両者の境界部分（以下、境界部）についても、各々質量 減少率を測定し、評価することが重要であると考えられる。そのた めには、補修部、無補修部および境界部における元の鉄筋の質量を 評価することが重要である。しかし鉄筋の径は長さ方向に一様でな いため、単位長さあたりの質量もばらつきをもっている。また補修
部、無補修部および境界部における鉄筋の単位長さあたりの質量も 同じとは限らないため、切断したときのそれぞれの部分における元 の質量の評価が困難である。さらに、質量減少率の評価のために、 不働態皮膜（以下、黒皮）を除去したみがき鉄筋を使用する場合は、 そのまま質量減少率を評価できるが、実際の状況を模擬するために 黒皮付きの鉄筋を使用する場合は、錆落としをした場合における黒 皮の質量の補正をどうするかが問題である。

今回、全ての鉄筋について単位長さ当りの質量を計測し、その変 動の分布から、補修部、無補修部および境界部のそれぞれの長さか ら元の質量を、その変動の幅を含めたうえで質量減少率を評価し、 補修効果の評価を試みた。本論文はそのように求めた質量減少率に よる補修効果の評価について報告するものである。

\section{2. 実験概要}

\section{1 試験体}

試験体は、図 1 に示すようにコンクリートのはつり範囲およびは つり深さを変化させることを想定して埋め込み方法を変化させた 3 本の鉄筋を埋め込み、あらかじめ試験体中央部分に鉄筋位置まで切 欠き部を設け、各種の断面修復材を施し、試験（暴露）面以外は、

\footnotetext{
本報告は，参考文献 2$) ， 3$ )を元にそのデー夕を見直し，解析し直して加筆・修正したものである。

$\begin{array}{ll}* \text { 関東職業能力開発大学校 准教授・博士 (工学) } & \text { Assoc. Prof., Kanto Polytechnic College, Dr. Eng. } \\ * * \text { 宇都宮大学工学研究科 教授.工博 } & \text { Prof., Dept. of Architecture and Civil Eng., Facult }\end{array}$

*** 宇都宮大学工学研究科 教授 $\cdot$ 工博

$* * *$ 独立行政法人建築研究所 博士 (学街
$* * * *$ 太平洋マテリアル(株) 博士 (工学)

Prof., Dept. of Architecture and Civil Eng., Faculty of Eng., Utsunomiya Univ., Dr. Eng. Building Research Institute, Ph. D.

Taiheiyo Material Corporation, Dr. Eng.
} 


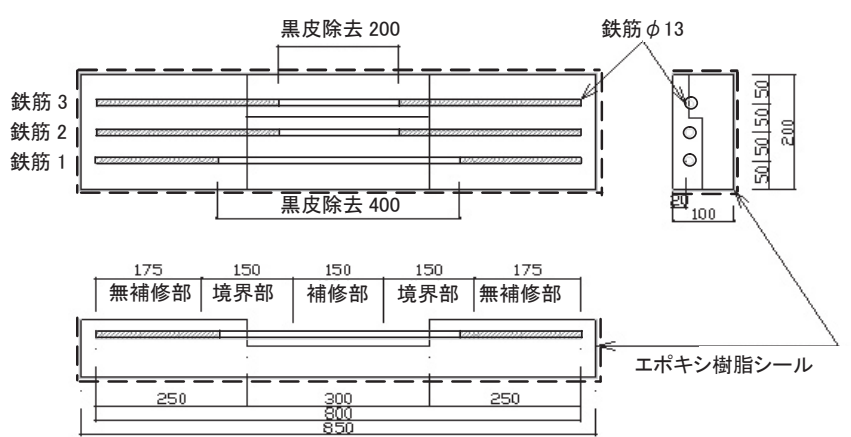

図 1 試験体の形状・ 寸法

エポキシ樹脂でコーティングしたものである。なお、黒皮除去は、

コンクリートをはつり取った部分では、鉄筋の錆落としをした状態

を、またコンクリート中に埋まった部分は、鉄筋が錆びて黒皮がな くなり、その不働態皮膜による保護効果がない状態を想定したもの である。そして、鉄筋 2 は、黒皮を除去した部分は寸べて補修材料 に接する状況、すなわち健全な部分が現れるまでコンクリートをは つり取ったことを、鉄筋 1 は、黒皮を除去した部分が一部コンクリ 一ト中に埋まっている状況、すなわち錆びた部分をコンクリート中 に残した状態を想定している。鉄筋 3 は、錆びた部分がコンクリー ト中に半分埋まり、上半分はコンクリートをはつり取ったことを模 擬している。また、黒皮除去の方法は研磨布を用いて行った。劣化、

表 1 実験の要因と水準

\begin{tabular}{l|l}
\hline 実験の要因 & \multicolumn{2}{|c}{ 水準 } \\
\hline \hline 塩化物量 $\left(\mathrm{Cl}^{-}\right)$の級 & $0.5 \mathrm{~kg} / \mathrm{m}^{3}, 1.5 \mathrm{~kg} / \mathrm{m}^{3}, 3.0 \mathrm{~kg} / \mathrm{m}^{3}$ \\
\hline はつり梁さ & 鉄筋の裏側まで, 鉄筋の上半分深さまで \\
\hline はつり範囲 & 健全部が現れるまで, 腐食が残る程度まで \\
\hline
\end{tabular}

表 2 選定した補修工法

\begin{tabular}{|c|c|c|c|c|}
\hline 防錆处理材 & 断面修復材 & 表面被覆材 & 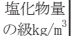 & 使用記号 \\
\hline \multirow{5}{*}{ なし } & \multirow{2}{*}{ 軽量PCM ${ }^{* 3}$ (SBR) } & なし & $\begin{array}{c}0.5 \\
1.5\end{array}$ & 0 -LP-0 \\
\hline & & 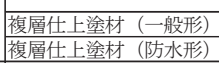 & $\begin{array}{l}\frac{1.5}{3.0} \\
3.0\end{array}$ & $\begin{array}{l}\text { 0-LP-E } \\
\text { 0-LP-F }\end{array}$ \\
\hline & 怪量 $\mathrm{PCM}^{* 3}$ (防錆剂入SBR) & なし & $\begin{array}{l}0.5 \\
1.5\end{array}$ & 0 -LPI-0 \\
\hline & \multirow{2}{*}{ 軽量EPM ${ }^{* 4}$} & なし & $\begin{array}{l}1.0 \\
0.5 \\
1.5\end{array}$ & 0-LE-0 \\
\hline & & 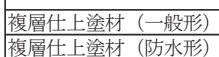 & $\begin{array}{l}3.0 \\
3.0\end{array}$ & $\begin{array}{l}0 \text {-LE-E } \\
0 \text {-LE-F }\end{array}$ \\
\hline \multirow{4}{*}{$\mathrm{PCP}^{* 1}$ (SBR) } & \multirow{3}{*}{$\mathrm{PCM}^{* 2}$ (SBR) } & 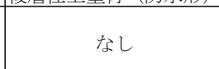 & $\frac{0.5}{1.5}$ & P-P-0 \\
\hline & & 複層仕上涂材（一般形） & $\begin{array}{l}3.0 \\
3.0\end{array}$ & P-P-E \\
\hline & & 複層仕上浚材 (防水形) & 3.0 & P-P-F \\
\hline & 軽量PCM*3. (SBR) & なし & $\begin{array}{l}0.5 \\
1.5\end{array}$ & P-LP-0 \\
\hline $\begin{array}{c}\mathrm{PCP} * 1 \quad(\mathrm{EVA}) \\
\mathrm{PCP}{ }^{* 1}(\text { (アクリル) }\end{array}$ & $\begin{array}{c}\mathrm{PCM}^{* 2} \text { (EVA) } \\
\mathrm{PCM}^{* 2}(\text { (アクリル) }\end{array}$ & $\begin{array}{l}\text { なし } \\
\text { なし } \\
\end{array}$ & $\begin{array}{l}1.5 \\
1.5 \\
\end{array}$ & $\begin{array}{c}\text { PEV-PEV-0 } \\
\text { PA-PA-0 }\end{array}$ \\
\hline PCP*1 (弾性アクリル) & $\mathrm{PCM}^{* 22}$ (弾性アクリル) & なし & $\begin{array}{l}1.5 \\
3.0\end{array}$ & PF-PF-0 \\
\hline PCP ${ }^{* 1}$ (防錆剤入SBR) & $\mathrm{PCM}^{* 2}$ (防錆剂入SBR) & なし & $\begin{array}{l}1.5 \\
3.0\end{array}$ & PI-PI-0 \\
\hline \multirow{4}{*}{ エポキシ樹脂 } & 軽量EPM ${ }^{* 4}$ & なし & $\begin{array}{l}0.5 \\
1.5\end{array}$ & E-LE-0 \\
\hline & $\frac{\mathrm{PCM}^{* 2}(\text { ア }}{\mathrm{PCM}^{* 2}(\text { エボキシ })}$ & $\frac{\text { なし }}{\text { なし }}$ & $\frac{1.5}{1.5}$ & $\frac{\text { E-PA-0 }}{\text { E-PEP-0 }}$ \\
\hline & \multirow{2}{*}{ EPM ${ }^{* 5}$} & なし & \begin{tabular}{|l|}
0.5 \\
1.5 \\
3.5
\end{tabular} & E-E-0 \\
\hline & & 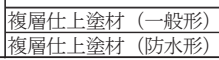 & $\begin{array}{l}3.0 \\
3.0 \\
\end{array}$ & $\begin{array}{l}\text { E-E-E } \\
\text { E-E-F }\end{array}$ \\
\hline \multicolumn{3}{|c|}{ なし（比較用） } & \begin{tabular}{|l}
0.5 \\
1.5 \\
3.0
\end{tabular} & $\mathrm{~N}$ \\
\hline
\end{tabular}

使用記号は、防錆処理材一断面修復材-表面被覆材の略号を示し、0は、なしを示寸

※1 PCP ポリマーセメントペースト

※2 PCM ポリマーセメントモルタル

$※ 4$ 軽量EPM 軽量エポキジ樹脂モルタル

※3 軽量PCM 軽量ポリマーセメントモルタル
因子およびはつり方についての実験要因と水準を、表 1 に示す。コ ンクリート、鉄筋などの使用材料は既報 ${ }^{1)}$ のとおりである。また、 試験体の補修面を下にしてコンクリートを打込んでおり、打込み底 面から鉄筋位置までは、 $20 \mathrm{~mm}$ と非常に小さく、ブリーディングの 影響による鉄筋位置での塩化物イオン濃度の差はないと考えられる。 本研究に用いた防錆処理材、断面修復材ならびに表面被覆材の種 類は、表 2 に、また、本研究に用いた断面修復材の基本物性は、 表 3 に示寸とおりである。

表 3 補修材料（断面修復材）の基本物性

\begin{tabular}{|c|c|c|c|c|c|c|c|}
\hline 補修材の種類 & $\begin{array}{c}\text { 圧縮 } \\
\text { 強さ } \\
\mathrm{N} / \mathrm{mm}^{2}\end{array}$ & $\begin{array}{c}\text { ヤング } \\
\text { 係数 } \\
\times 10^{4} \\
\mathrm{~N} / \mathrm{mm}^{2}\end{array}$ & $\begin{array}{c}\text { 曲げ } \\
\text { 強さ } \\
\mathrm{N} / \mathrm{mm}^{2}\end{array}$ & $\begin{array}{c}\text { 吸水率 } \\
\text { g/l }\end{array}$ & 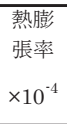 & $\begin{array}{l}\text { 乾燥 } \\
\text { 収縮 } \\
\times 10^{-4}\end{array}$ & $\begin{array}{c}\text { 透気性 } \\
\mathrm{mm}\end{array}$ \\
\hline 軽量PCM(SBR) & 9.0 & 0.37 & 3.9 & 238 & 14.5 & 17.3 & 0.0 \\
\hline 軽量EPM & 14.9 & 0.18 & 11.6 & 12 & 78.6 & 5.2 & 0.0 \\
\hline PCM (SBR) & 39.8 & 1.17 & 11.5 & 137 & 11.6 & 7.7 & 0.0 \\
\hline PCM (EVA) & 39.8 & 1.74 & 12.1 & 154 & 18.2 & 11.4 & 0.0 \\
\hline PCM (アクリル) & 57.5 & 2.67 & 14.6 & 144 & 14.6 & 4.7 & 0.0 \\
\hline PCM (弾性アクリル) & 14.9 & 0.96 & 5.8 & 140 & 12.3 & 8.9 & 0.5 \\
\hline PCM (エポキシ) & 29.2 & 1.34 & 3.1 & 153 & 19.0 & 17.2 & 0.0 \\
\hline EPM & 32.8 & 0.87 & 14.4 & 102 & 46.3 & 2.1 & 2.5 \\
\hline
\end{tabular}

(注) 吸水率 (JISA6203)、乾燥収縮 $\left(20^{\circ} \mathrm{C}, 60 \% \mathrm{RH}, \mathrm{CO}_{2} 5 \%, 30 \mathrm{~d}\right.$ よる中性化深さ)

\section{2 埋め込む前の鉄筋の一様性の評価}

暴露試験に供した試験体に使用した全ての鉄筋 210 本について、 その質量を長さで除して単位長さ当りの質量を求め、その確率分布 を求めた。その結果を表 4 に示す。今回使用した鉄筋における単位 長さあたりの質量の変動は $0.45 \%$ あ゙あ、以下では、これだけの変 動があるものとして解析する。

表 4 鉄筋単位長さあたりの単位質量の一様性

\begin{tabular}{c|c}
\hline 本数 & $210($ 本 $)$ \\
\hline 最大値 & $1.0188(\mathrm{~g} / \mathrm{mm})$ \\
\hline 最小值 & $1.0017(\mathrm{~g} / \mathrm{mm})$ \\
\hline 平均值 & $1.0086(\mathrm{~g} / \mathrm{mm})$ \\
\hline 標隻偏差 & $0.0045(\mathrm{~g} / \mathrm{mm})$ \\
\hline 変動係数 & $0.45(\%)$ \\
\hline
\end{tabular}

\section{3 黒皮除去部の質量評価}

今回の実験では、コンクリートに埋め込む前に補修時の錆落とし を想定して、部分的に鉄筋の黒皮を除去している。その除去した黒 皮分の質量については、除去後の質量を元の質量から差し引いて単 位長さ当りの黒皮の質量減を調べた。その結果を表 5 に示す。

表 5 元の鉄筋の単位質量に対する黒皮の単位質量の比

\begin{tabular}{c|c|c}
\hline & 平均値 & 標準偏差 \\
\hline \hline $200 \mathrm{~mm}$ 除去 & 0.0147 & 0.0103 \\
\hline $400 \mathrm{~mm}$ 除去 & 0.0199 & 0.0079 \\
\hline 全体 & 0.0164 & 0.0099 \\
\hline
\end{tabular}

表 5 の值は、鉄筋の錆落としを想定して部分的に磨いた後の黒皮 における元の鉄筋に対寸る質量比であり、おおよそ $1.64 \%$ の減少で あり、後述する薬品浸漬による黒皮除去よりも多く削り取ったこと になるが、極端に細くなっていないと考えられる。

\section{4 屋外暴露試験条件}

屋外暴露試験は, 茨城県つくば市の（独）建築研究所の屋外暴 露試験場で実施した。屋外暴露試験場の気象条件は、既報 ${ }^{1)}$ に示 したとおりである。試験材齢は、短期暴露が塩化物量の級 $3.0 \mathrm{~kg} / \mathrm{m}^{3}$ 
の場合 2.4 年 (2 年 5 ケ月)、同 $1.5 \mathrm{~kg} / \mathrm{m}^{3}$ の場合 3.2 年 (3 年 2 ケ

月）および同 $0.5 \mathrm{~kg} / \mathrm{m}^{3}$ の場合 8 年であり、長期暴露がいずれも 19.9 年（19 年 11 ケ月）である。また、試験体数は各材齢 1 体とした。

\section{5 評価項目および評価方法}

補修効果の評価項目は、鉄筋に生じた錆の面方向への広がりの抑

制を指標とする発錆面積率と鉄筋の深さ方向への進行の抑制を指標 とする質量減少率とし、その両者の関係から評価した。

補修部、無補修部および境界部の各部における鉄筋のコンクリー トに埋め込む前の質量は、元の鉄筋の長さをL $(\mathrm{mm})$ 、質量を $\mathrm{W}_{0}$ $(\mathrm{g})$ 、黒皮除去部の長さをり $(\mathrm{mm})$ 、黒皮を部分的に除去した質量 を $\mathrm{W}_{0},(\mathrm{~g})$ 、暴露試験後に切断した鉄筋の補修部の長さを $\ell_{1}$ $(\mathrm{mm})$ 、境界部における両側の長さの和を $\ell_{2} \quad(\mathrm{~mm})$ 、両側無補修 部の長さの和を $\ell_{3} \quad(\mathrm{~mm})$ 、切断したときの切代を $\mathrm{d}(\mathrm{mm})$ として、 次のように推定した (図2参照)。ただし切代はすべて同じ幅と仮定 した。また、 $\mathrm{L}=\ell_{1}+\ell_{2}+\ell_{3}+4 \mathrm{~d}$ である。

補修部: $\left(\frac{\mathrm{W}_{0}}{\mathrm{~L}}-\frac{\mathrm{W}_{0}-\mathrm{W}_{0}}{\ell}\right) \times \ell_{1}$

無補修部： $\frac{\mathrm{W}_{0}}{\mathrm{~L}} \times \ell_{3}$

境界部の黒皮部分 : $\frac{\mathrm{W}_{0}}{\mathrm{~L}} \times\left(\mathrm{L}-\ell-\mathrm{l}_{3}-2 \times \mathrm{d}\right)$

境界部の黒皮除去部分 : $\left(\frac{\mathrm{W}_{0}}{\mathrm{~L}}-\frac{\mathrm{W}_{0}-\mathrm{W}_{0}}{\ell}\right) \times\left(l-\ell_{1}-2 \times \mathrm{d}\right)$
暴露試験後の質量減少率の評価は、錆落としをして質量を計測し、 元の鉄筋の鉄筋から差し引いて質量減少量を求め、質量減少率を計 算した。補修部は、黒皮をあらかじめ除去してあるので、式（1） に示寸ように質量減少率は、最初の鉄筋の質量から暴露試験後に錆

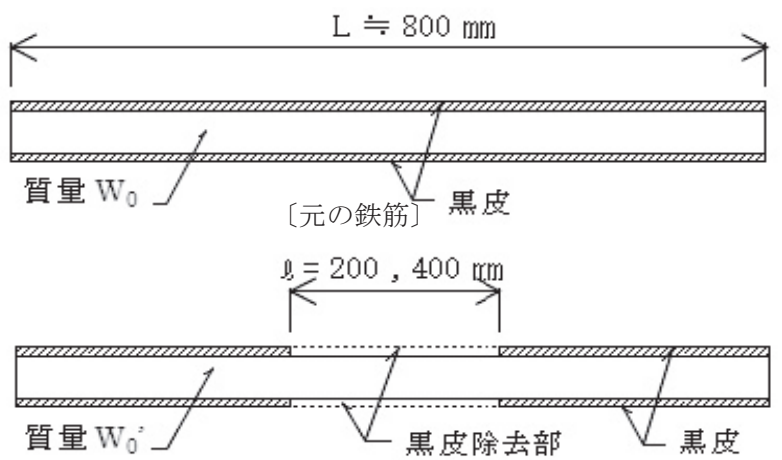

〔埋め込み前に部分的に黒皮を除去した鉄筋〕

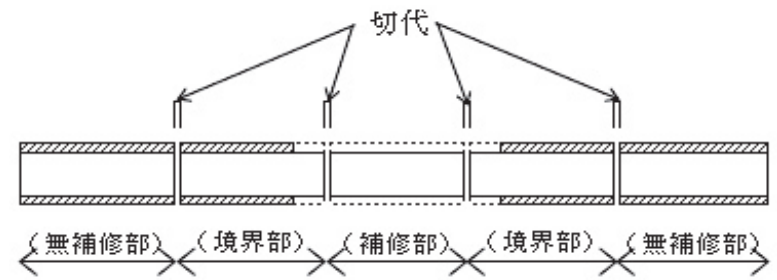

〔暴露試験後、補修部,境界部，無補修部の各部に切断した鉄筋〕

図 2 各部の鉄筋の長さおよび質量の評価

表 6 短期暴露期間における鉄筋の質量減少率（\%)

\begin{tabular}{|c|c|c|c|c|c|c|c|c|c|c|}
\hline \multirow{2}{*}{$\begin{array}{l}\text { 塩化物 } \\
\text { 量の粐 } \\
\left(\mathrm{kg} / \mathrm{m}^{3}\right)\end{array}$} & \multirow{2}{*}{$\begin{array}{l}\text { 部位および } \\
\text { 補修工法 }\end{array}$} & \multicolumn{3}{|c|}{ 境界部 } & \multicolumn{3}{|c|}{ 補修部 } & \multicolumn{3}{|c|}{ 無補修部 } \\
\hline & & №.1 & №.2 & No.3 & No.1 & No.2 & No.3 & No.1 & No.2 & No.3 \\
\hline \multirow{8}{*}{0.5} & $0-\mathrm{LP}-0$ & 1.00 & 0.17 & 0.19 & 1.21 & 0.40 & 0.42 & -0.65 & 0.04 & 0.19 \\
\hline & $0-\mathrm{LPI}-0$ & 0.42 & 0.20 & 0.06 & 0.64 & 0.52 & 0.33 & 0.13 & 0.09 & 0.03 \\
\hline & $0-\mathrm{LE}-0$ & 0.59 & 0.41 & 0.27 & 0.49 & 0.34 & 0.31 & -0.01 & 0.02 & -0.05 \\
\hline & $\mathrm{P}-\mathrm{P}-0$ & 0.35 & 0.19 & 0.07 & 0.66 & 0.63 & 0.34 & 0.14 & 0.06 & 0.00 \\
\hline & $\mathrm{P}-\mathrm{LP}-0$ & 0.33 & 0.14 & 0.15 & 0.51 & 0.54 & 0.54 & 0.12 & 0.00 & 0.08 \\
\hline & $E-L E-0$ & 0.61 & 0.32 & 0.28 & 0.35 & 0.56 & 0.41 & -0.02 & -0.10 & -0.04 \\
\hline & $E-E-0$ & 0.44 & 0.29 & 0.26 & 0.35 & 0.45 & 0.42 & 0.09 & 0.07 & -0.09 \\
\hline & $\mathrm{N}$ & 0.26 & \multicolumn{2}{|c|}{0.03} & \multicolumn{3}{|c|}{0.41} & \multicolumn{3}{|c|}{0.03} \\
\hline \multirow{14}{*}{1.5} & $0-\mathrm{LP}-0$ & 0.15 & -0.28 & 0.04 & 0.41 & 0.32 & 0.10 & -0.15 & -0.14 & -0.22 \\
\hline & $0-\mathrm{LPI}-0$ & -0.17 & 0.09 & 0.03 & 0.04 & 0.25 & 0.32 & -0.43 & -0.16 & -0.07 \\
\hline & $0-\mathrm{LE}-0$ & 0.09 & -0.18 & -0.06 & 0.33 & 0.02 & 0.05 & -0.24 & -0.37 & -0.38 \\
\hline & $\mathrm{P}-\mathrm{P}-0$ & 0.08 & 0.02 & -0.21 & 0.20 & -0.15 & 0.12 & -0.29 & -0.28 & -0.22 \\
\hline & $\mathrm{P}-\mathrm{LP}-0$ & 0.20 & 0.05 & -0.05 & 0.32 & 0.15 & 0.20 & -0.31 & -0.18 & -0.14 \\
\hline & $\mathrm{PEV}-\mathrm{PEV}-0$ & 0.08 & 0.10 & 0.24 & 0.17 & 0.24 & 0.22 & -0.27 & -0.17 & -0.02 \\
\hline & $\mathrm{PA}-\mathrm{PA}-0$ & 0.31 & -0.16 & 0.15 & 0.48 & 0.88 & 0.17 & -0.01 & -0.21 & -0.13 \\
\hline & $\mathrm{PF}-\mathrm{PF}-0$ & 0.08 & 0.09 & -0.20 & 0.17 & 0.15 & 0.10 & -0.28 & -0.11 & -0.31 \\
\hline & $\mathrm{PI}-\mathrm{PI}-0$ & 0.10 & -0.03 & 0.00 & 0.19 & 0.29 & 0.40 & -0.31 & -0.09 & -0.17 \\
\hline & $\mathrm{E}-\mathrm{LE}-0$ & 0.27 & -0.07 & 0.18 & 0.19 & 0.14 & 0.14 & -0.23 & -0.21 & -0.07 \\
\hline & $\mathrm{E}-\mathrm{PA}-0$ & 0.20 & -0.19 & -0.11 & 0.45 & 0.32 & 0.03 & -0.25 & -0.22 & -0.25 \\
\hline & $\mathrm{E}-\mathrm{PEP}-0$ & 0.04 & -0.11 & -0.14 & 0.30 & 0.32 & 0.07 & -0.18 & -0.25 & -0.28 \\
\hline & $E-E-0$ & 0.14 & 0.10 & 0.06 & 0.26 & -0.02 & 0.40 & -0.24 & -0.22 & -0.15 \\
\hline & $\mathrm{N}$ & -0.05 & \multicolumn{2}{|c|}{0.22} & \multicolumn{3}{|c|}{-0.41} & \multicolumn{3}{|c|}{-0.18} \\
\hline \multirow{13}{*}{3.0} & $0-\mathrm{LP}-\mathrm{E}$ & 0.64 & 0.26 & 0.46 & 0.35 & 0.29 & 0.35 & 0.18 & 0.00 & -0.03 \\
\hline & $0-\mathrm{LP}-\mathrm{F}$ & 0.55 & 0.23 & 0.21 & 0.45 & 0.18 & 0.20 & -0.05 & 0.05 & 0.01 \\
\hline & $0-\mathrm{LE}-\mathrm{E}$ & 0.46 & 0.35 & 0.20 & 0.55 & 0.28 & 0.42 & -0.04 & -0.13 & 0.05 \\
\hline & $0-\mathrm{LE}-\mathrm{F}$ & 0.42 & 0.35 & 1.80 & 0.90 & 0.18 & -3.31 & 0.07 & 0.10 & 0.14 \\
\hline & $\mathrm{P}-\mathrm{P}-0$ & 0.56 & 0.32 & 1.68 & 0.76 & 0.37 & -3.09 & 0.40 & 0.19 & 0.31 \\
\hline & $\mathrm{P}-\mathrm{P}-\mathrm{E}$ & 0.37 & 0.22 & 2.51 & 1.04 & 0.36 & -4.34 & 0.31 & 0.15 & 0.08 \\
\hline & $\mathrm{P}-\mathrm{P}-\mathrm{F}$ & 0.19 & 0.16 & 0.65 & 1.04 & 0.44 & -1.00 & -0.08 & 0.19 & -0.08 \\
\hline & $\mathrm{PF}-\mathrm{PF}-0$ & 0.17 & 0.36 & 0.84 & 1.16 & 0.41 & -1.14 & 0.19 & 0.36 & 0.00 \\
\hline & $\mathrm{PI}-\mathrm{PI}-0$ & 0.37 & 0.48 & 0.48 & 0.40 & 0.36 & 0.41 & 0.09 & 0.17 & 0.16 \\
\hline & $E-E-0$ & 0.25 & 0.26 & 0.62 & 0.33 & 0.19 & 0.42 & 0.31 & 0.26 & 0.08 \\
\hline & $E-E-E$ & 0.55 & 0.78 & 0.57 & 0.69 & 1.09 & 0.80 & 0.05 & -0.02 & 0.06 \\
\hline & $E-E-F$ & 0.21 & 0.32 & 1.39 & 1.12 & 0.42 & -1.97 & -0.11 & -0.06 & 0.03 \\
\hline & $\mathrm{N}$ & 0.11 & \multicolumn{2}{|c|}{0.34} & \multicolumn{3}{|c|}{-0.07} & \multicolumn{3}{|c|}{0.15} \\
\hline
\end{tabular}

使用記号は、防錆処理材 - 断面修復材 - 表面被覆材の略号を示し、0は、なしを示す。

P:ポリマーセメント系、PEV:ポリマーセメント系 (EVA)、PA:ポリマーセメント系(アクリル)、PF:ポリマーセメント系(弾性アクリル)

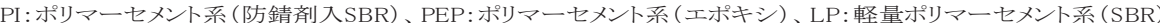

LPI : 軽量ポリマーセメント系 (防錆剤入SBR)、E:エポキシ樹脂系、LE: 軽量エポキシ樹脂系

表面被覆材 $\mathrm{E}$ : 複層仕上塗材 (一般形) 、表面被覆材 $\mathrm{F}$ : 複層仕上塗材(防水形) 
表 7 長期暴露期間における鉄筋の質量減少率（\%)

\begin{tabular}{|c|c|c|c|c|c|c|c|c|c|c|}
\hline \multirow{2}{*}{$\begin{array}{l}\text { 㸃化物 } \\
\text { 量の級 } \\
\left(\mathrm{kg} / \mathrm{m}^{3}\right) \\
\end{array}$} & \multirow{2}{*}{ 補修工法 } & \multicolumn{3}{|c|}{ 境界部 } & \multicolumn{3}{|c|}{ 補修部 } & \multicolumn{3}{|c|}{ 無補修部 } \\
\hline & & No.1 & No.2 & No.3 & No.1 & №.2 & No.3 & No.1 & No.2 & No.3 \\
\hline \multirow{8}{*}{0.5} & $0-\mathrm{LP}-0$ & 0.31 & 0.12 & 0.16 & 0.34 & 0.58 & 0.21 & -0.17 & 0.01 & 0.05 \\
\hline & $0-$ LPI-0 & 0.05 & 0.00 & 0.05 & 1.00 & 0.50 & 0.44 & 0.08 & 0.10 & 0.08 \\
\hline & $0-L E-0$ & 1.27 & 1.12 & 1.05 & 0.66 & 0.52 & 1.36 & 0.34 & 0.14 & 0.25 \\
\hline & $\mathrm{P}-\mathrm{P}-0$ & 0.21 & 0.04 & 0.05 & 0.40 & 0.62 & 0.58 & -0.03 & -0.08 & -0.15 \\
\hline & $\mathrm{P}-\mathrm{LP}-0$ & 0.37 & -0.05 & 0.09 & 0.27 & 0.61 & 0.42 & -0.09 & -0.13 & -0.05 \\
\hline & $\mathrm{E}-\mathrm{LE}-0$ & 1.13 & 0.76 & 0.55 & 0.95 & 0.75 & 0.42 & 0.06 & 0.04 & -0.02 \\
\hline & $E-E-0$ & 0.44 & 0.29 & 0.36 & 0.49 & 0.28 & 0.63 & -0.04 & 0.01 & 0.04 \\
\hline & $\mathrm{N}$ & 0.19 & \multicolumn{2}{|c|}{0.06} & \multicolumn{3}{|c|}{0.44} & \multicolumn{3}{|c|}{-0.14} \\
\hline \multirow{14}{*}{1.5} & $0-\mathrm{LP}-0$ & 0.49 & 0.35 & 0.31 & 0.77 & 0.45 & 0.52 & 0.14 & 0.30 & 0.14 \\
\hline & $0-\mathrm{LPI}-0$ & 0.54 & 0.03 & 0.11 & 0.43 & 0.57 & 0.21 & 0.19 & 0.21 & 0.22 \\
\hline & $0-\mathrm{LE}-0$ & 1.18 & 0.91 & 1.25 & 0.87 & 0.54 & 1.67 & 0.36 & 0.34 & 0.17 \\
\hline & $\mathrm{P}-\mathrm{P}-0$ & 0.33 & 0.16 & 0.10 & 0.56 & 0.31 & 0.38 & 0.01 & -0.03 & -0.15 \\
\hline & $\mathrm{P}-\mathrm{LP}-0$ & 0.43 & 0.25 & 0.35 & 0.11 & 0.32 & 0.31 & -0.13 & -0.04 & -0.18 \\
\hline & $\mathrm{PEV}-\mathrm{PEV}-0$ & 1.46 & 0.31 & 0.21 & 0.00 & 0.56 & 0.08 & 0.00 & -0.05 & 0.30 \\
\hline & $\mathrm{PA}-\mathrm{PA}-0$ & 0.56 & 0.59 & 0.06 & 0.56 & -0.35 & 0.50 & 0.28 & 0.25 & 0.20 \\
\hline & $\mathrm{PE}-\mathrm{PE}-0$ & 0.52 & 0.23 & 0.53 & 0.50 & 0.50 & 0.28 & -0.01 & 0.07 & 0.11 \\
\hline & $\mathrm{PI}-\mathrm{PI}-0$ & 0.38 & -0.70 & 0.15 & 0.45 & 1.01 & 0.53 & 0.16 & 0.57 & 0.00 \\
\hline & E-LE-0 & 1.14 & 0.94 & 0.72 & 1.08 & 0.32 & 0.60 & 0.00 & 0.03 & 0.08 \\
\hline & $\mathrm{E}-\mathrm{PA}-0$ & 0.44 & 0.23 & 0.35 & 0.49 & 0.47 & 0.38 & -0.06 & -0.07 & 0.04 \\
\hline & $\mathrm{E}-\mathrm{PEP}-0$ & 0.45 & 0.22 & 0.30 & 0.57 & 0.42 & 0.59 & 0.06 & 0.18 & 0.20 \\
\hline & $E-E-0$ & 0.66 & 0.92 & 0.60 & 0.49 & 1.37 & 0.75 & 0.26 & 0.15 & 0.10 \\
\hline & $\mathrm{N}$ & 0.28 & \multicolumn{2}{|c|}{0.12} & \multicolumn{3}{|c|}{0.29} & \multicolumn{3}{|c|}{0.02} \\
\hline \multirow{13}{*}{3.0} & $0-\mathrm{LP}-\mathrm{E}$ & 0.91 & 0.95 & 0.86 & 0.78 & 0.49 & 0.66 & 0.97 & 0.88 & 0.63 \\
\hline & $0-\mathrm{LP}-\mathrm{F}$ & 0.97 & 0.59 & 0.48 & 0.88 & 0.65 & 1.06 & 0.73 & 0.45 & 0.34 \\
\hline & $0-\mathrm{LE}-\mathrm{E}$ & 1.65 & 1.63 & 1.52 & 1.21 & 1.58 & 1.56 & 0.87 & 0.73 & 0.64 \\
\hline & $0-\mathrm{LE}-\mathrm{F}$ & 1.35 & 0.79 & 0.96 & 0.66 & 0.50 & 1.29 & 0.02 & 0.05 & 0.31 \\
\hline & $\mathrm{P}-\mathrm{P}-0$ & 0.62 & 0.59 & 0.67 & 0.62 & 0.45 & 0.54 & 0.66 & 0.81 & 1.58 \\
\hline & $\mathrm{P}-\mathrm{P}-\mathrm{E}$ & 0.64 & 0.65 & 0.66 & 0.54 & 0.66 & 0.35 & 0.88 & 0.73 & 0.80 \\
\hline & $\mathrm{P}-\mathrm{P}-\mathrm{F}$ & 0.67 & 0.44 & 0.84 & 0.57 & 0.26 & 0.54 & 0.21 & 0.35 & 0.53 \\
\hline & $\mathrm{PF}-\mathrm{PF}-0$ & 0.76 & 0.72 & 0.74 & 0.63 & 0.76 & 0.57 & 0.71 & 1.01 & 1.10 \\
\hline & $\mathrm{PI}-\mathrm{PI}-0$ & 0.70 & 0.95 & 0.82 & 0.72 & 0.65 & 0.62 & 0.36 & 0.32 & 0.97 \\
\hline & $E-E-0$ & 2.11 & 1.87 & 3.96 & 1.24 & 0.46 & 5.61 & 1.11 & -0.01 & 2.25 \\
\hline & $E-E-E$ & 3.02 & 2.36 & 1.75 & 4.35 & 1.49 & 2.91 & 1.13 & 1.46 & 1.92 \\
\hline & $\mathrm{E}-\mathrm{E}-\mathrm{E}$ & 1.79 & 1.85 & 1.64 & 2.25 & 3.09 & 2.46 & 0.06 & 0.36 & 0.35 \\
\hline & $\mathrm{N}$ & 0.64 & \multicolumn{2}{|c|}{0.73} & \multicolumn{3}{|c|}{0.72} & \multicolumn{3}{|c|}{0.69} \\
\hline
\end{tabular}

落としをした鉄筋の質量を差し引いて、最初の鉄筋質量に対する百 分率で表した。また、無補修部は、あらかじめ黒皮を除去していな いため、錆落としをするときに同時に健全な黒皮も除去されてしま う。そのため錆がない部分の黒皮の質量分を補正する必要があり、 その質量減少率の計算式は、式（2）によって求めた。

$$
\begin{gathered}
\Delta w_{1}=\frac{\mathrm{W}_{1-} \mathrm{W}}{\mathrm{W}_{1}} \times 100 \\
\Delta w_{2}=\frac{\mathrm{W}_{2}-\mathrm{W}}{\mathrm{W}_{2}} \times 100-\mathrm{W}_{\mathrm{S}} \times \frac{100-\mathrm{S}}{100}
\end{gathered}
$$

ここで $\Delta w_{1}$ : 黒皮除去部分の質量減少率（\%） $\mathrm{W}_{1}$ : 黒皮を除去 した鉄筋の想定される最初の質量 $(\mathrm{g}) 、 \mathrm{~W}$ : 暴露試験後に錆落とし をした鉄筋質量 $(\mathrm{g}) 、 \Delta w_{2}$ : 黒皮付き部分の質量減少率 $(\%)$ 、 $\mathrm{W}_{2}$ : 黒皮付きの鉄筋の想定される最初の質量 $(\mathrm{g}) 、 w_{\mathrm{s}}$ : 黒皮の質 量百分率 $(\%) 、 S$ : 発錆面積率 $(\%)$ 。

なお、黒皮の質量百分率は、無補修部の鉄筋で発錆面積率が $0 \%$ のものを用いてクエン酸 2 アンモニウム液に浸漬して黒皮を除去し、 求められた值の平均值 $0.83 \%$ を用いることとした。また、境界部に ついては、式（1）と式（2）で計算される值を黒皮部分の全体に対 する長さ比で配分して求めた。

\section{3. 実験結果}

屋外暴露試験期間別に鉄筋質量減少率の測定結果を表 6 ～7 亿示す 表6の短期（2.4，3.2，8年）の補修部の鉄筋3において、-3.0\%を
超える質量減少率が見られる。表 4 によれば、鉄筋の単位長さ当た りの質量の変動における標準偏差 $\sigma$ は、 $0.45 \%$ であり、3 0 では 1. 35\%である。従ってー1. $35 \%$ を超える質量減少率は、ほとんどあ り得ないと考えられる。補修部においては最初に黒皮を除去してお り、その際に部分的に大きく削り取ったことも考えられる。短期暴 露期間のデータについて、特に塩化物量の級が $3.0 \mathrm{~kg} / \mathrm{m}^{3}$ の測定の 際には質量減少率の解析方法が確定しておらず、生データのままで 保存していたことがあり、長期暴露においては測定し直しなどの措 置が講じられているが、短期暴露においては測定結果の見直しが不 可能なこともあり、ー $1.35 \%$ を回るデータについては合理性が疑 われるので 4 つのデータ（表 $6: 3.0 \mathrm{~kg} / \mathrm{m}^{3}$ の補修部で鉄筋№.3の 塗り潰し箇所）は削除し、以下の解析では使用しないこととする。

$\mathrm{N}$ については、No.1，No.2，№.3 とで黒皮除去部分が異なるため、 境界部では、№.1 と N o. 2 ・ 3 とで別々に質量減少率を算定し、補修部、 無補修部では、各々黒皮を除去した部分と黒皮を残した部分の環境 による差はないため、鉄筋№.による区別はしていない。なお、N で 黒皮を除去した補修部と黒皮を残した無補修部とを比較すると、質 量減少率は補修部の方が大きく、不働態皮膜である黒皮の腐食に対 する保護効果が認められる。また、表 7 より、塩化物の級が大きく なると、質量減少率が大きくなる傾向にあることがみとめられる。

\section{4. 考察}

\section{1 塩化物量の違いによる補修効果}

図 3 は、塩化物量の級別に短期および長期暴露試験における境界 部、補修部および無補修部における質量減少率を小さい方から順次 
(0. $5 \mathrm{~kg} / \mathrm{m}^{3}$ の級)

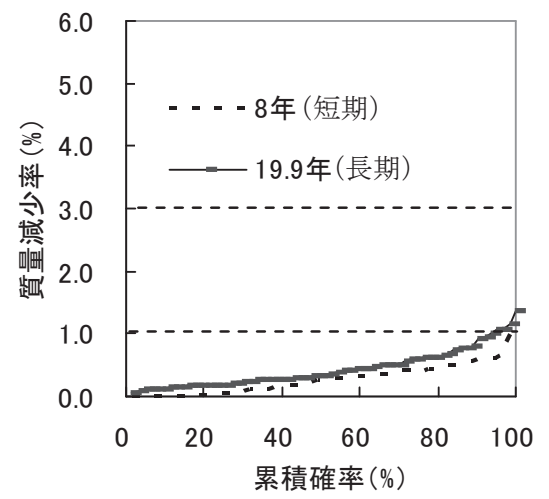

$\left(1.5 \mathrm{~kg} / \mathrm{m}^{3}\right.$ の級 $)$

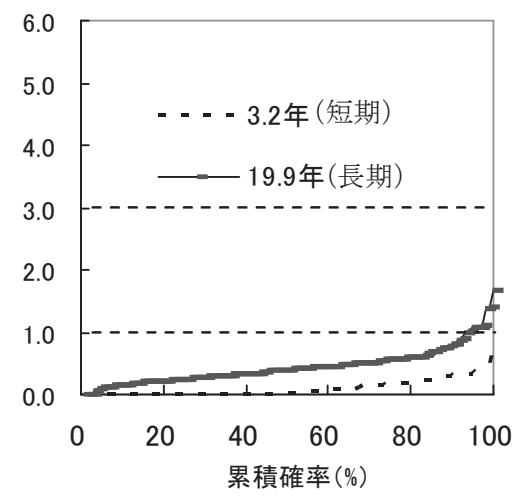

(3. $0 \mathrm{~kg} / \mathrm{m}^{3}$ の級)

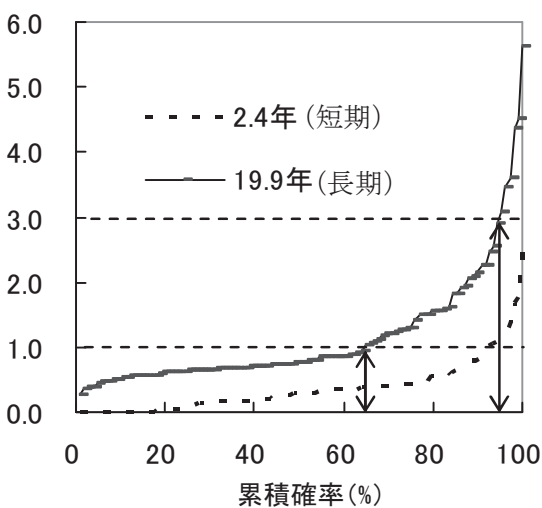

図 3 塩化物量の違いによる質量減少率累積確率

累積していった場合の累積確率を示している。短期暴露において、

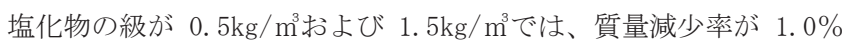
以上となる確率はほとんど見られず、一方 $3.0 \mathrm{~kg} / \mathrm{m}^{3}$ の場合は、 $1.0 \%$ 以上となる確率が $9 \%$ 程度ある。また長期暴露においては、

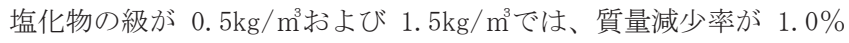
以上となる確率は、ともに $7 \%$ 程度であるが、塩化物量の級が $3.0 \mathrm{~kg} / \mathrm{m}$ になると、質量減少率が $1.0 \%$ 以上となる確率は $36 \%$ あ、 さらに、ひび割れが発生するとされる $3.0 \%$ 以上となる確率は $6 \%$ ある。これらのことから塩化物量の級が $0.5 \mathrm{~kg} / \mathrm{m}^{3}$ および $1.5 \mathrm{~kg} / \mathrm{m}^{3}$ では断面修復工法によって全体的に鉄筋腐食が抑制されているが、 $3.0 \mathrm{~kg} / \mathrm{m}^{3}$ になると全体的に腐食の進行が大きくなり、断面修復工法 による補修効果が期待できなくなることがわかる。

\section{2 鉄筋のはつり出し方法が補修効果に及ぼす影響}

図 4 は、鉄筋腐食部分を、寸なわち健全である黒皮が現れるまで 十分にはつり取りを行わなかった事を想定している鉄筋 1 と、鉄筋 腐食部分を十分にはつり取った事を想定している鉄筋 2 の各部位別 の質量減少率を比較したものである。また、図 5 は、鉄筋 2 と切欠 き部の裏面のほぼ半分がコンクリート中にある鉄筋 3 の各部位別の 質量減少率を比較したものである。各図中の実線は、(鉄筋 1 また は鉄筋 3-鉄筋 2）の質量減少率における差の平均值を示したもの である。この結果、鉄筋 1 と 2 を比較すると、境界部および補修部 における差については、鉄筋 1 の方がそれぞれ全体の平均で $0.19 \%$ 、 $0.15 \%$ 上回っていることから、鉄筋 1 の腐食が進んでいることがわ かる。また鉄筋 2 と 3 を比較すると、境界部において、鉄筋 3 の方
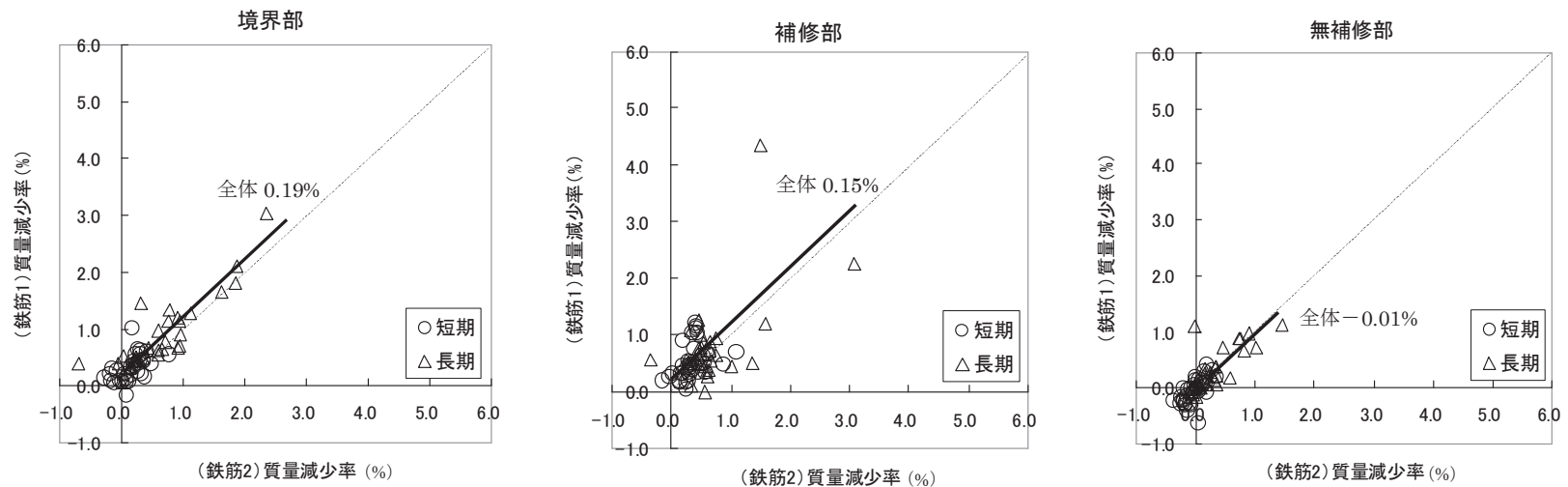

図 4 鉄筋 1 と鉄筋 2 によるつり方の違いによる質量減少率
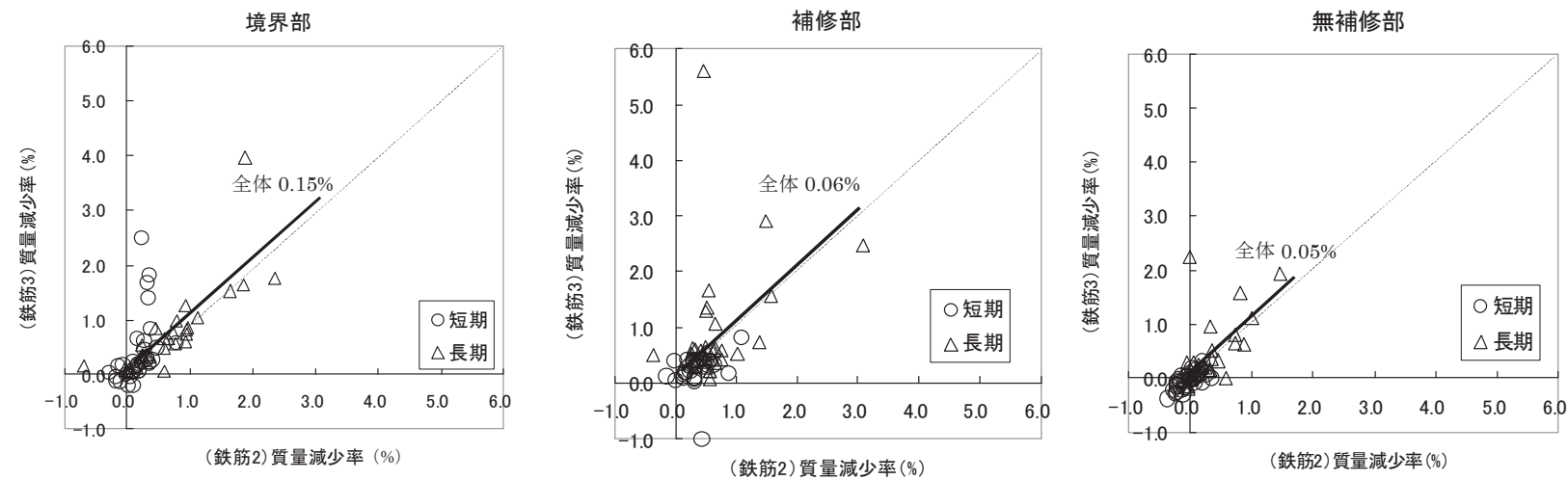

図 5 鉄筋 2 と鉄筋 3 によるはつり方の違いによる質量減少率 
が平均で $0.15 \%$ 上回っており、補修部では鉄筋 3 の方が、 $0.06 \%$ 、 無補修部でも $0.05 \%$ 上回っている。以上のことから、はつりの際、 健全な鉄筋が現れるまでコンクリートをはつり取ることが重要であ るといえる。
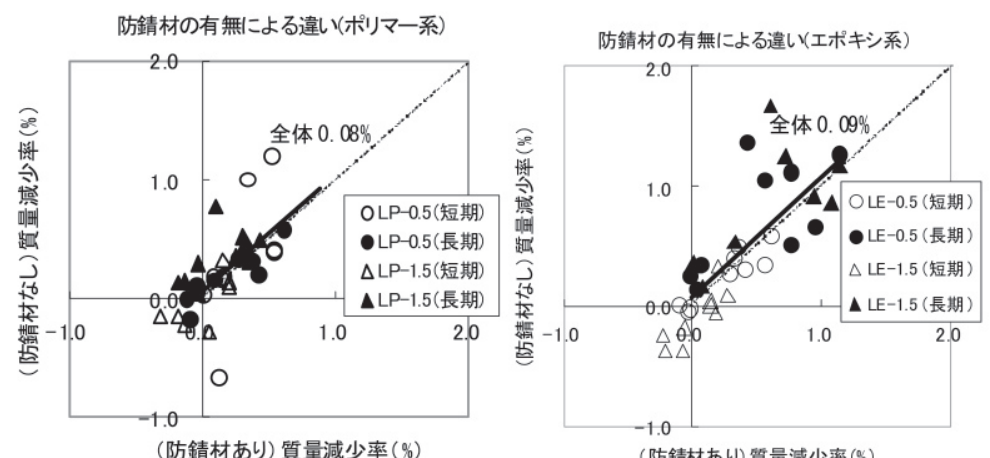

図 6 防錆材のあり・なしの違いによる質量減少率
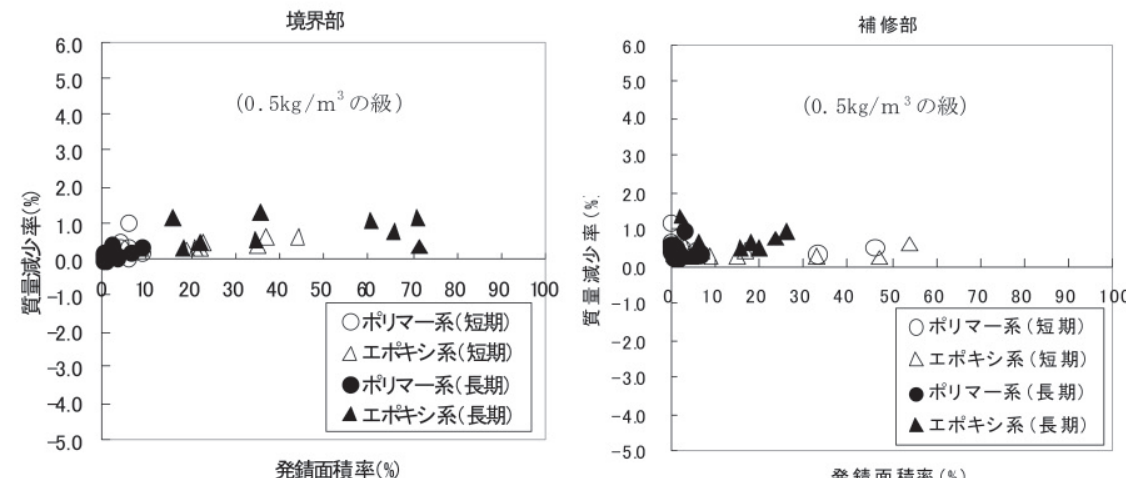

境界部

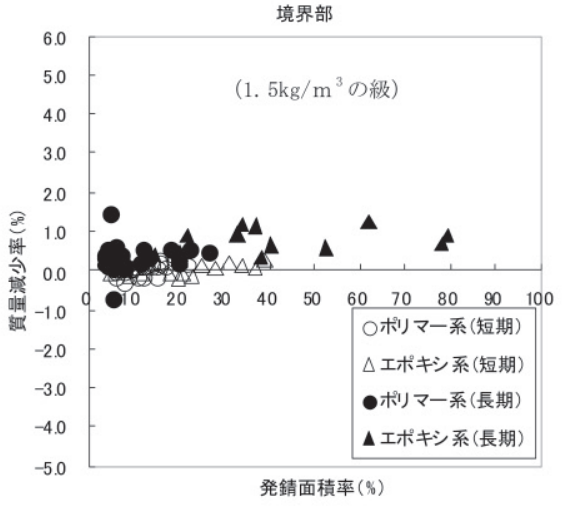

境界部
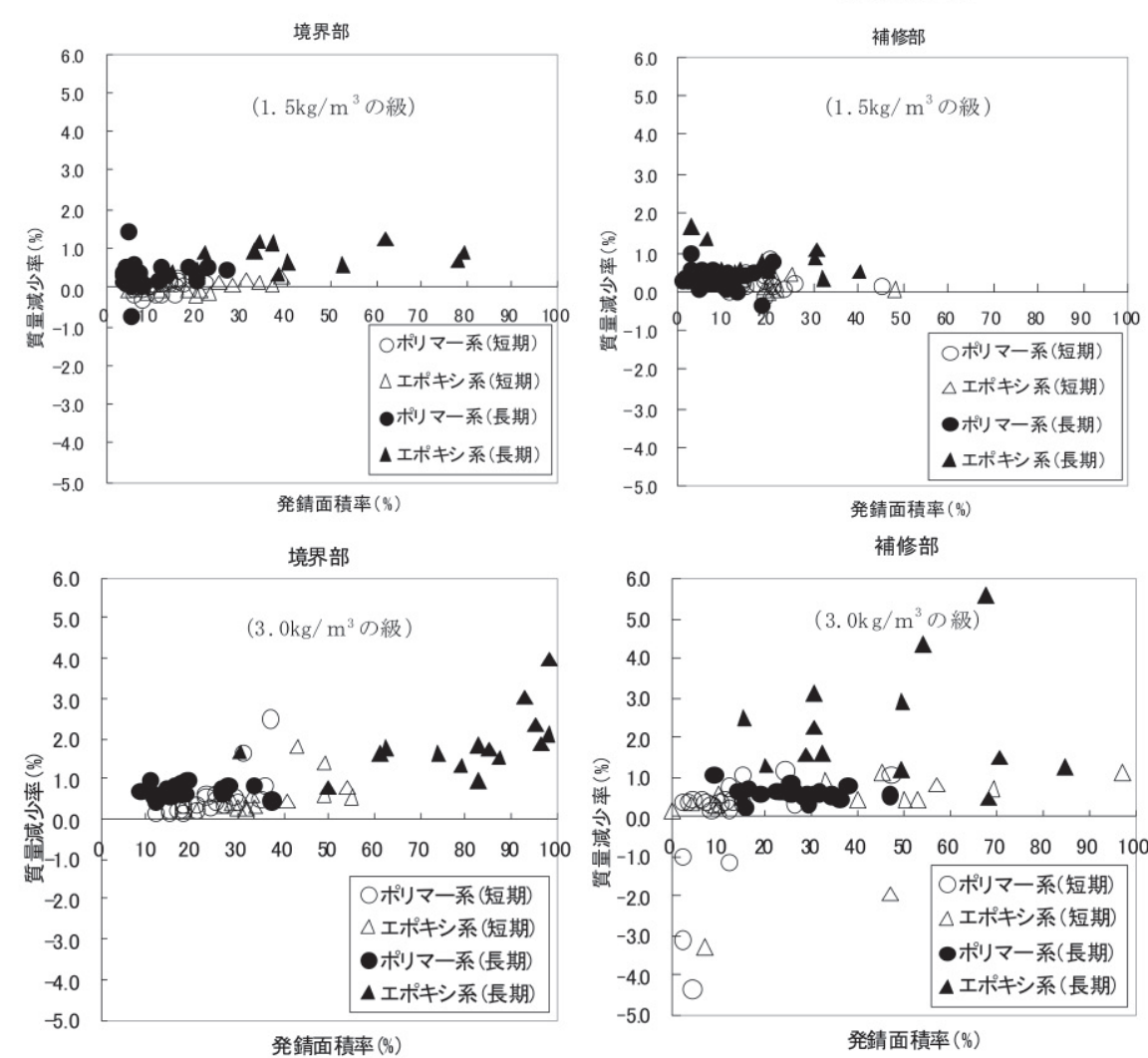

\section{3 鉄筋防錆材の有無が補修効果に及ぼす影響}

図 6 は、短期および長期暴露において補修効果が比較できる代表

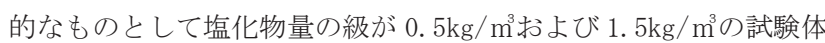

ポリマーセメント系
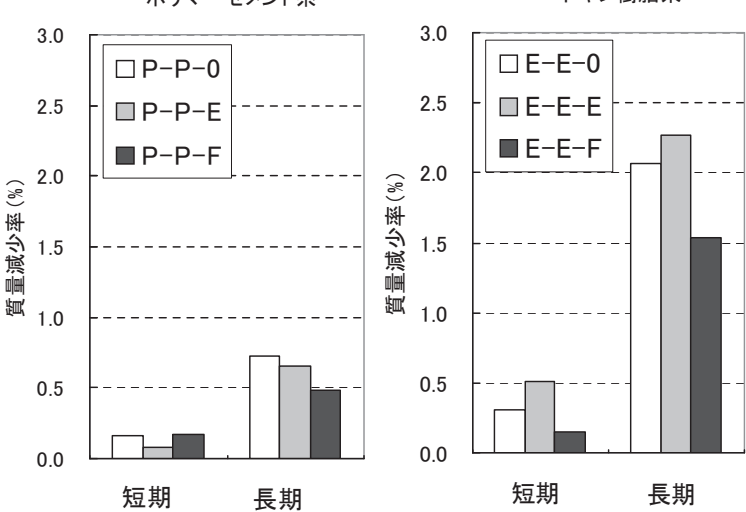

図 7 表面被覆材の違いによる比較
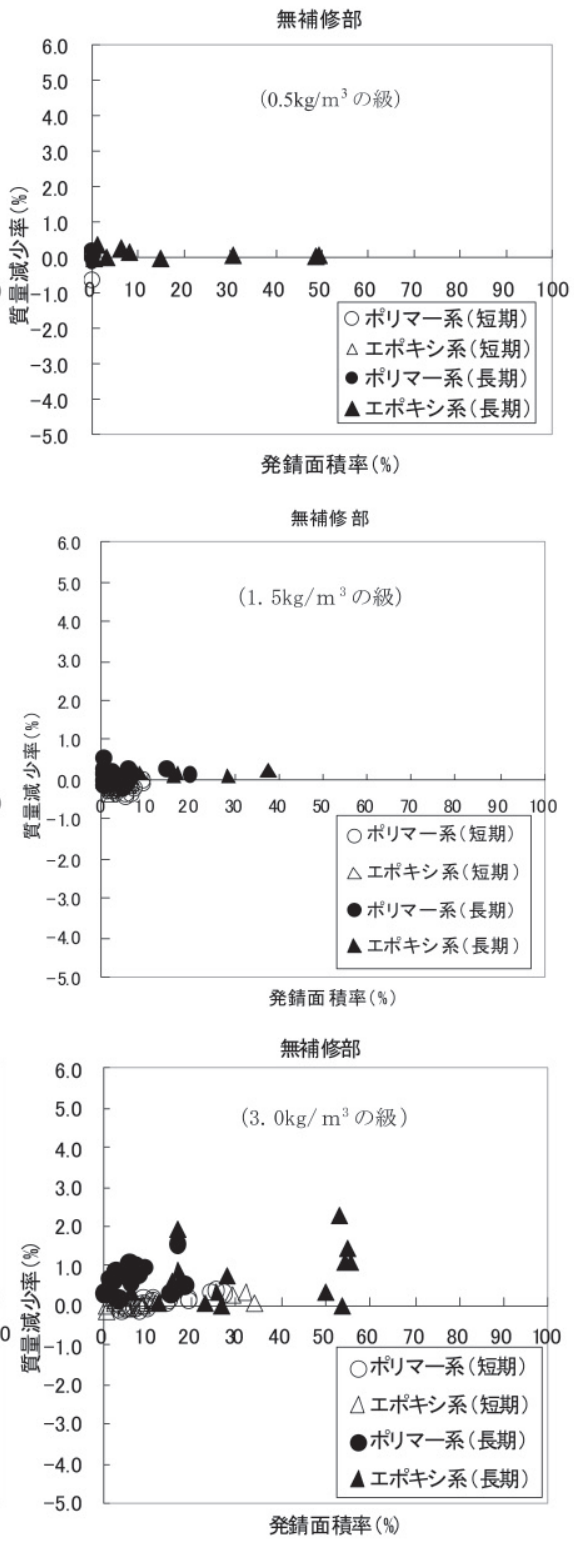

図 8 塩化物量の違いによる発錆面積率と質量減少率の関係（長期暴露） 
において、ポリマーセメント系およびエポキシ樹脂系の鉄筋防錆材 を施したものと施していないものを比較した図である。各図中の実 線は、「防錆材なし一防錆材あり」の質量減少率における差の平均 值を示したものであり、防錆材なしの方がポリマーセメント系の平 均で $0.08 \%$ 、エポキシ樹脂系の平均で $0.09 \%$ 上回っていることから、 ポリマーセメント系およびエポキシ樹脂系ともに防錆材を施さなか った場合より防錆材の効果が若干あるといえる。

\section{4 表面被覆材の有無が補修効果に及ぼす影響}

図 7 は、短期および長期暴露において塩化物量の級が $3.0 \mathrm{~kg} / \mathrm{m}^{3}$ の場合にポリマーセメント系およびエポキシ樹脂系の補修材を施し たものに対して、表面被覆材の補修効果が比較できる代表的な試験 体にそれぞれ一般形と防水形の複層仕上塗材を施したものと、仕上 塗材を施さなかったものを全ての平均值で比較した図である。この 結果、短期，長期暴露およびポリマーセメント系，エポキシ樹脂系 ともに、表面被覆材を施さないものに比べて、防水形複層仕上塗材 を施した効果がみられることがわかる。

\section{5 発錆面積率と質量減少率の関係}

図 8 は、塩化物量の級別に、各部位（境界部、補修部、無補修 部）毎に発錆面積率と質量減少率との関係を示した図である。これ らを見ると、塩化物量の級が $0.5 \mathrm{~kg} / \mathrm{m}^{3}$ と $1.5 \mathrm{~kg} / \mathrm{m}^{3}$ では、発錆面積 率の増加に対する質量減少率の増加傾向は小さく、腐食が表面的に 広がる傾向にあることが見てとれる。また、ポリマーセメント系と エポキシ樹脂系とを比較すると、エポキシ樹脂系における発錆面積 率の方が大きい傾向にある。塩化物量の級が $3.0 \mathrm{~kg} / \mathrm{m}^{3}$ になると、 発錆面積率の増加に対する質量減少率の増加傾向は大きく、腐食が 表面的な広がりだけでなく深さ方向にも進行している傾向にあるこ とがわかる。また、エポキシ樹脂系の方がポリマーセメント系より も発錆面積率、質量減少率とも大きいことがわかる。この理由とし て、エポキシ樹脂系の方が水分や酸素などの物質の透過性が小さく、 境界部分における腐食環境の違いが大きくなることから腐食が促進 され、防錆処理材と鉄筋との間で腐食が進行することが考えられる。 なお、定量的な検討は、今後の課題である。特に境界部および補修 部において発錆面積率、質量減少率ともに腐食の進行が顕著である。

\section{6 鉄筋の質量減少率の増加傾向}

既報 ${ }^{1)}$ の発錆面積率と同様に、質量減少率についても、 $\Delta w=$ $\mathrm{at}^{\mathrm{b}}$ とおき、実測值と回帰式の差の二乗和が最小になるいわゆる最

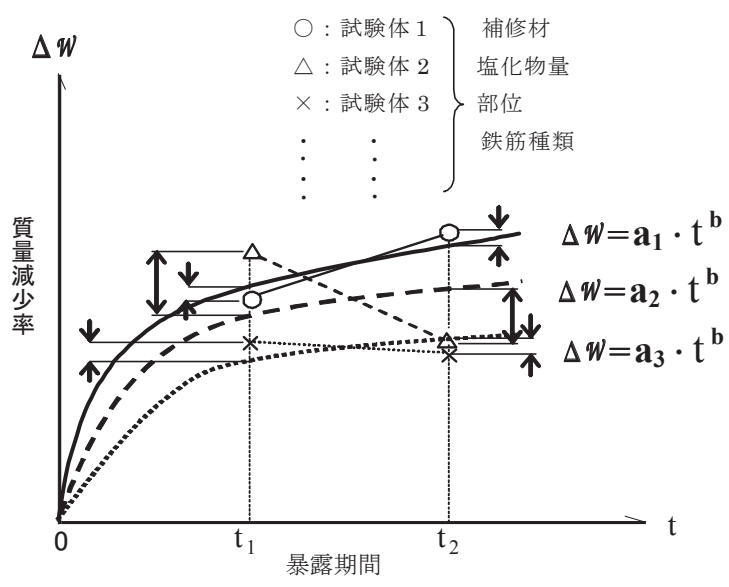

図 9 質量減少率増加傾向の概念図
小二乗法によって b の值を検討することとした。すなわち、式 （3）において b の值を一時固定して各 $\mathrm{j}$ について最小二乗法で a j を決定し、そのときの $\Delta$ を求める。次に b の值を変化させ、 $\Delta$ が最小となる $\mathrm{b}$ の值を小数点以下第 1 位まで求めた。その結果を表 8 に示す。ただし、0.1未満は、0.1とした。

$$
\Delta=\sum_{j} \sum_{i=1}^{2}\left(\Delta w_{\mathrm{i}}-\mathrm{a}_{j} \mathrm{t}_{\mathrm{i}}^{\mathrm{b}}\right)^{2} \rightarrow \min \quad \cdots(3)
$$

表 8 によれば、ポリマーセメント系では、b の值が境界部、補修

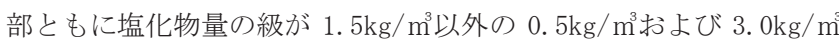
で 0.1 未満となっており、これは補修後のごく短期間に少し腐食が 進むものの、長期的には安定して腐食の進行がないことを意味して いる。一方、無補修部では、0.8 および 1.0 であり、時間の経過と ともに腐食が進行する傾向にあることがみとめられる。また、エポ キシ樹脂系では、いずれも b 值は、 0.6 から 1.0 となっており、 補修後も腐食が進行する傾向にあることがわかる。

表 8 質量減少率増加傾向值の一覧（b の值）

\begin{tabular}{|c||c|c|c|c|c|c|}
\hline \multicolumn{1}{|c||}{ 材料系 } & \multicolumn{3}{|c|}{ ポリマーセメント系 } & \multicolumn{3}{c|}{ エポキシ樹脂系 } \\
\hline 塩化物量の級 $(\mathrm{kg} / \mathrm{m} 3)$ & 0.5 & 1.5 & 3.0 & 0.5 & 1.5 & 3.0 \\
\hline 境界部 & 0.1 & 1.0 & 0.1 & 0.9 & 1.0 & 0.6 \\
\hline 補修部 & 0.1 & 0.4 & 0.1 & 0.7 & 0.9 & 0.8 \\
\hline 無補修部 & 1.0 & 1.0 & 0.8 & 1.0 & 1.0 & 1.0 \\
\hline 全体 & \multicolumn{3}{c|}{0.2} & \multicolumn{4}{c|}{0.8} \\
\hline
\end{tabular}

\section{5. 結論}

約 20 年におよぶ長期屋外暴露試験の結果は、次のようにまとめ られる。

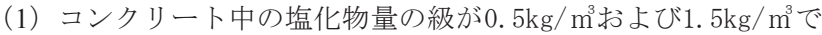
は断面修復工法によって鉄筋腐食が抑制されているが、3. $0 \mathrm{~kg} /$ $\mathrm{m}^{3}$ になると全体的に腐食の進行が大きくなり、断面修復工法に よる補修の効果が期待できなくなることがわかる。

（2）断面修復の際、鉄筋 3 は、鉄筋 1 ・2 亿比べて質量減少率が大き く鉄筋の裏側まではつり取らないと、防錆材・断面修復材、表 面被覆材の効果が期待できなくなる。

（3）鉄筋防錆処理材を施すことで、鉄筋腐食の補修効果が向上す るが、エポキシ樹脂系の材料に比べて、ポリマーセメント系 材料の方がより効果が認められる。

（4）断面修復材に表面被覆材を併用寸ると、鉄筋腐食の抑制効果 が若干期待できる傾向が見られる。

（5）塩化物量の級が $3.0 \mathrm{~kg} / \mathrm{m}^{3}$ になると、発錆面積率が増加するに つれて質量減少率も増加する傾向にあり、腐食が表面的な広が りだけでなく深さ方向にも広がっていくことがわかる。

（6）ポリマーセメント系は、短期暴露期間に質量減少率が増加し、 その後長期暴露期間にわたって増加はあまり見られないが、エ ポキシ樹脂系では、進行がとまらないといら傾向が見られる。

\section{参考文献}

1) 西村眞治ほか 3 名:断面修復工法による鉄筋腐食補修効果の評価に関する 長期暴露実験,日本建築学会構造系論文集第 633 号,pp1913-1920.2008.11 
2) 西村眞治ほか 3 名:鉄筋防錆材および断面修復材による塩害劣化補修工法 の長期暴露実験, 日本建築学会大会学術講演梗概集 A-1,pp12251226.2007 .8

3) 西村眞治ほか 3 名:鉄筋防錆材および断面修復材による塩害劣化補修工法 の長期暴露実験（その 2) 日本建築学会大会学術講演梗概集 A-1,pp12251226.2008 .8

4) 西村眞治ほか 3 名:鉄筋防錆材および断面修復材による塩害劣化補修工法 の長期暴露実験（その 3)，日本建築学会大会学術講演梗概集 A-1,pp12251226.2009 .9

5) 松林裕二,桝田佳寛:断面修復材による鉄筋腐食補修工法の評価に関する実 験,日本建築学会技術報告集第 13 号,pp33-38.2001.7

6) 花栄浩ほか 5 名:鉄筋防錆材及び断面修復による鉄筋コンクリート造の塩 害劣化補修効果に関寸る研究(その 1 2), 日本建築学会大会学術講演梗概 集 A-1,pp143-46.1990.9

7) 花栄浩ほか 4 名:鉄筋防錆材及び断面修復による鉄筋腐食補修工法の評価
に関する実験(その 1～2), 日本建築学会大会学術講演梗概集 A-1,pp189 192.1991 .9

8）松林裕二,桝田佳寬:鉄筋防錆材および断面修復材による鉄筋腐食補修工法 の評価に関する屋外暴露実験, 日本建築学会大会学術講演梗概集 A1,pp275-276.2000.9

9) 日本建築学会:鉄筋コンクリート造の耐久性調査、診断および補修指針 案・同解説, 1997.2

10) 浜田秀則ほか 2 名:塩害により劣化した鉄筋コンクリート部材の補修効果 に関する実験的考察,コンクリート工学論文集,第 3 巻,第 2 号, pp8595.1992.7

11）栘田佳寛ほか 6 名:表面被覆材および浸透性吸水防止材による鉄筇コンク リートの塩害劣化抑制効果に関する実験, 日本建築学会構造系論文報告集 第 433 号,ppl-10.1992,3

（2010年 1 月10日原稿受理，2010年 5 月31日採用決定） 